\title{
EKSISTENSI MASYARAKAT HUKUM ADAT DAN LEMBAGA-LEMBAGA ADAT DI ACEH DALAM PENYELENGGARAAN KEISTIMEWAAN DAN OTONOMI KHUSUS DI ACEH
}

\author{
Kurniawan \\ Fakultas Hukum Universitas Syiah Kuala \\ Email: Kurniawanfh@yahoo.com
}

\begin{abstract}
This study aims to explain the existence of indigenous people and traditional institutions in Aceh in the administration the Aceh's special autonomy. In addition, it explains the duties, functions and authority of traditional institutions in Aceh nowadays. This study is normative legal research. This study examines library materials that acquired through literature study. The technical/ approach used is the statute approach, by using deductive analysis. The results of the study indicate that the existence indigenous people and traditional institutions in Aceh have shown their role in local community life in Aceh. This is caused by the community in Aceh has fulfilled the requirements of indigenous people as stated by the applicable law. The existence of traditional institutions in Aceh essentially has the function and role as a vehicle for public participation in the administration of the Government of Aceh provincial level and the Regency/municipality level in the area of security, peace, harmony, and public order. In addition, those traditional institutions also have some number of authorities as mandated by Article 4 Qanun Aceh No. 10 of 2008 concerning traditional Institution.
\end{abstract}

Keywords: Indigenous People, Traditional Institution, Aceh's Special Autonomy

\begin{abstract}
Abstrak
Penelitian ini bertujuan menjelaskan eksistensi (kedudukan) masyarakat hukum adat dan lembaga-lembaga adat di Aceh dalam penyelenggaraan Keistimewaan dan Otonomi Khusus Aceh. Selain itu, menjelaskan tugas, fungsi, dan wewenang lembaga-lembaga adat yang ada di Aceh saat ini. Penelitian ini merupakan penelitian hukum normatif (legal research). Kajian ini menelaah bahan pustaka yang diperoleh melalui studi pustaka. pendekatan yang digunakan ialah pendekatan peraturan perundang-undangan (statute approach), dengan menggunakan penalaran deduktif. Hasil kajian menunjukkan bahwa keberadaan (eksistensi) masyarakat hukum adat dan kelembagaan adat di Aceh telah menunjukkan kiprahnya dalam tata kehidupan masyarakat di Aceh. Hal tersebut disebabkan oleh karena masyarakat hukum di Aceh telah memenuhi syarat-syarat masyarakat hukum adat sebagaimana yang disebutkan dalam peraturan perundang-undangan yang berlaku. Keberadaan lembaga-lembaga adat di Aceh hakikatnya memiliki fungsi dan peran sebagai wahana partisipasi masyarakat dalam penyelenggaraan Pemerintahan Aceh dan Pemerintahan Kabupaten/Kota di bidang keamanan, ketenteraman, kerukunan, dan ketertiban masyarakat. Selain itu, lembaga-lembaga adat tersebut juga memiliki sejumlah kewenangan sebagaimana yang diamanatkan Pasal 4 Qanun Aceh Nomor 10 Tahun 2008 tentang Lembaga Adat.
\end{abstract}

Kata kunci: Masyarakat Hukum Adat, Lembaga Adat, Otonomi Khusus Aceh.

\section{A. Pendahuluan}

Sistem Pemerintahan Negara Kesatuan Republik Indonesia menurut Undang-Undang Dasar Negara Republik Indonesia Tahun 1945 mengakui dan menghormati satuan-satuan pemerintahan daerah yang bersifat khusus atau bersifat istimewa. Perjalanan ketatanegaraan Republik Indonesia telah menempatkan Aceh sebagai satuan pemerintahan yang bersifat istimewa dan khusus, terkait dengan karakter khas sejarah perjuangan masyarakat Aceh yang memiliki ketahanan dan daya juang yang tinggi (Hardi, 1992: 152). Ketahanan dan daya juang yang tinggi tersebut bersumber dari pandangan hidup yang berlandaskan Syari'at Islam yang melahirkan budaya Islam yang kuat dan budaya Islam yang kuat tersebut termanifestasikan dalam kehidupan adat, sosial dan politik masyarakat Aceh (Kaoy Syah, Lukman Hakiem, 2000: 7).

Beberapa kali amandemen UUD 1945 yang dilakukan pada tahun 1999 sampai tahun 2002 telah menimbulkan berbagai perubahan pada batang tubuh UUD 1945 termasuk pada Pasal 18 mengenai Pemerintahan Daerah yang menjadi cikal bakal pembentukan lembaga-lembaga adat di daerah. Pasal 18 B UUD 1945 hasil amandemen menyebutkan sebagai berikut. 
Ayat (1), Negara mengakui dan menghormati satuan-satuan pemerintahan daerah yang bersifat khusus atau bersifat istimewa yang diatur dengan undang-undang. Ayat (2), Negara mengakui dan menghormati kesatuan-kesatuan masyarakat hukum adat beserta hak-hak tradisionalnya sepanjang masih hidup dan sesuai dengan perkembangan masya-rakat dan prinsip Negara Kesatuan Republik Indonesia, yang diatur dalam undang-undang.

Wujud manisfestasi pengakuan dan jaminan terhadap kesatuan-kesatuan masyarakat hukum adat sebagaimana yang diamanatkan oleh Konstitusi, maka kemudian ditetapkan UndangUndang Nomor 44 Tahun 1999 tentang Keistimewaan Aceh yang mana pada Pasal 3 ayat (1) menyebutkan bahwa: "Keistimewaan merupakan pengakuan dari bangsa Indonesia yang diberikan kepada Daerah karena perjuangan dan nilai-nilai hakiki masyarakat yang tetap dipelihara secara turun temurun sebagai landasan spiritual, moral, dan kemanusiaan". Keistimewaan yang dimaksud dalam Undang-Undang Nomor 44 Tahun 1999 ini sebagaimana yang dijelaskan dalam Pasal 1 angka 8 yaitu kewenangan khusus untuk menyelenggarakan kehidupan beragama, adat, pendidikan, dan peran ulama dalam penetapan kebijakan daerah".

Adapun menyangkut bentuk penyelenggaraan keistimewaan yang diberikan kepada Aceh berdasarkan Undang-Undang Nomor 44 athun 1999 tentang Keistimewaan Aceh menyangkut empat hal sebagaimana yang diamanatkan dalam Pasal 3 ayat (2): "Penyelenggaraan Keistimewaan meliputi: a. Penyelenggaraan kehidupan beragama; $b$. Penyelenggaraan kehidupan adat; c. Penyelenggaraan pendidikan; dan d. Peran ulama dalam penetapan kebijakan Daerah. Terkait dengan keistimewaan yang berkaitan dengan penyelenggaraan kehidupan adat sebagaimana yang disebutkan dalam huruf $b$ tersebut merupakan dasar hukum Pemerintah Aceh untuk menjabarkan lebih lanjut kedalam bentuk berbagai Qanun atau Peraturan Daerah (Perda) di Aceh.

Melalui Undang-Undang Nomor 44 Tahun 1999 tentang Keistimewaan Aceh tersebut, Pemerintah Aceh diberi wewenang oleh Pemerintah Pusat untuk menetapkan berbagai kebijakan dalam upaya pemberdayaan, pelestarian, dan pengembangan adat serta lembaga adat di wilayahnya yang dijiwai dan sesuai dengan syari'at Islam sebagaimana yang diamanatkan Pasal 6. Selain itu juga Undangundang tersebut memberi wewenang kepada Pemerintah Aceh untuk membentuk lembaga adat dan mengakui lembaga-lembaga adat yang sudah ada sesuai dengan kedudukannya masing-masing di Propinsi, Kabupaten/Kota, Kecamatan,
Pemukiman, dan Kelurahan/Desa atau Gampong (desa) sebagaimana yang diamanatkan Pasal 7 yang dituangkan dalam bentuk Qanun atau Peraturan Daerah. Atas dasar itu Pemerintah Aceh mengeluarkan Qanun Aceh Nomor 9 Tahun 2008 tentang Pembinaan Kehidupan Adat dan Adat Istiadat dan Qanun Aceh Nomor 10 Tahun 2008 tentang Lembaga Adat. Selain itu dalam rangka memperkuat sekaligus menindak lanjuti UndangUndang Nomor 44 Tahun 1999 tersebut, Pemerintah Aceh telah mengeluarkan Peraturan Daerah (Perda) Nomor 7 Tahun 2000 tentang Penyelenggaraan Kehidupan Adat.

Selanjutnya, berdasarkan Undang-Undang Nomor 11 Tahun 2006 tentang Pemerintahan Aceh, telah menempatkan Gubernur dalam kedudukannya sebagai wakil pemerintah, memiliki tugas dan wewenang mengkoordinasikan 5 hal yang salah satunya adalah dalam pembinaan dalam penyelenggaraan kekhususan dan keistimewaan Aceh sebagaimana yang diamanatkan Pasal 43 ayat (1). Selanjutnya dalam Pasal 96 (1) menyebutkan bahwa: "Lembaga Wali Nanggroe merupakan kepemimpinan adat sebagai pemersatu masyarakat yang independen, berwibawa, dan berwenang membina dan mengawasi penyelenggaraan kehidupan lembaga-lembaga adat, adat istiadat, dan pemberian gelar/derajat dan upacaraupacara adat lainnya".

Dalam Undang-Undang Nomor 11 Tahun 2006 tentang Pemerintahan Aceh terdapat bab yang secara khusus mengatur tetang Lembaga Adat yang mana disebutkan dalam Pasal 98 khususnya ayat (3) dan Pasal 99 Undang-Undang Nomor 11 Tahun 2006 tentang Pemerintahan Aceh dan juga hal yang sama diatur dalam Pasal 2 ayat (2) Qanun Aceh Nomor 10 Tahun 2008 tentang Lembaga Adat. Adapun Lembaga-lembaga adat di Aceh sebagaimana yang diatur baik dalam Pasal 98 ayat (3) maupun Pasal 2 ayat (2) Qanun Aceh Nomor 10 Tahun 2008 tersebut adalah sebagai berikut: 1 . Majelis Adat Aceh (MAA), 2. Imeum Mukim, 3. Imeum Chik, 4. Tuha Lapan, 5. Keuchik, 6. Imeum Meunasah, 7. Tuha Peut, 8. Kejruen Blang, 9. Panglima Laot, 10. Pawang Glee, 11. Peutua Seuneubok, 12. Hariya Peukan, dan 13. Syahbanda. Berdasarkan ketentuan Pasal 2 ayat (2) Qanun Aceh Nomor 10 Tahun 208 tentang Lembaga Adat, secara struktural menempatkan Majelis Adat Aceh (MAA) sebagai lembaga adat yang membawahi lembaga-lembaga adat lain seperti: Imuem mukim; Imuem chik; Keuchik; Tuha peuet; Tuha lapan; Imuem meunasah; Keujreun blang; Panglima laot; Pawang glee; Peutua seuneubok; Haria peukan; Syahbanda. Pembinaan kehidupan adat dan adat istiadat di Aceh dilakukan 
sesuai dengan perkembangan keistimewaan dan kekhususan Aceh yang berlandaskan pada nilainilai syari'at Islam dan dilaksanakan oleh Wali Nanggroe sebagaimana yang diamanatkan dalam Pasal 99 ayat (1).

Berdasarkan latar belakang sebagaimana yang di kemukakan di atas, maka yang menjadi permasalahan, pertama, bagaimanakah kedudukan (eksistensi) masyarakat hukum adat dan lembagalembaga adat di Aceh dalam penyelenggaraan keistimewaan dan otonomi khusus di Aceh?, dan kedua, apakah Peranan (tugas, fungsi dan wewenang) lembaga-lembaga adat di Aceh dalam penyelenggaraan keistimewaan dan otonomi khusus di Aceh?

\section{B. Metode Penelitian}

Penelitian ini adalah penelitian hukum normatif (legal research), yaitu penelitian untuk mengkaji norma, kaedah dan asas hukum (Rony Hanitijo Soemitro, 1983: 10). Studi/kajian ini menelaah bahan pustaka yang diperoleh melalui studi pustaka dengan mengumpulkan dan mempelajari literaturliteratur, berbagai peraturan perundang-undangan, jurnal hukum, ensiklopedia, serta mengutip beberapa pendapat para sarjana yang relevan. Pendekatan yang digunakan ialah pendekatan peraturan perundang-undangan (statute approache), yaitu pendekatan dengan menjadikan legislasi dan regulasi tertentu sebagai dasar kajian dalam mengupas setiap permasalahan yang diangkat (Peter Mahmud Marzuki, 2007: 37). Cara/teknik analisis data menggunakan penalaran/metode berpikir deduktif.

\section{Hasil Penelitian dan Pembahasan \\ 1. Sejarah Perkembangan Adat Istiadat dan Hukum Adat di Aceh}

Aceh merupakan salah satu provinsi di Indonesia yang sangat menjunjung tinggi adat istiadat dalam masyarakatnya. Hal ini terlihat dengan masih berfungsinya institusi-institusi adat di tingkat gampông (desa) atau mukim (kecamatan), meskipun Undang Undang Nomor 5 Tahun 1974 tentang Pemerintah daerah ketika itu berusaha menghilangkan fungsi mukim, keberadaan Imum Mukim di Aceh.

Dalam masyarakat Aceh yang sangat senang menyebut dirinya dengan Ureueng Aceh (orang Aceh) terdapat institusi-institusi adat di tingkat gampông (desa) dan mukim (kecamatan). Institusi tersebut juga merupakan bagian daripada lembaga pemerintahan yang kemudian dikenal dengan lembaga daerah.
Jadi, setiap kejadian dalam kehidupan bermasyarakat, Ureueng Aceh (orang Aceh) selalu menyelesaikan masalah tersebut secara adat yang berlaku dalam masyarakatnya baik secara personal maupun secara kelembagaan (Mahdi Syahbandir, 1995: 3).

Perkembangan kehidupan adat dan hukum adat Aceh tidak pernah lepas dari sejarah masuk dan berkembangnya Islam di Aceh, sehingga dikenal dalam hadih maja (Falsafah hidup) rakyat Aceh dengan istilah "Adat Bersendi Syara', Syara' Bersendi Adat" adalah falsafah yang menjadi simbol pelaksanaan kehidupan bermasyarakat di Aceh (Djuned T, 1977: 38). Ketika hukum adat kuat, maka hukum agama juga kuat. Begitu juga sebaliknya. Agama bersumber dari Al-Quran dan hadits, sedangkan adat bersumber dari Sultan dengan musyawarah yang digali berdasarkan sumber keagamaan. Sehingga banyak adat Aceh yang tidak lepas dari pengaruh syara'.

Adat istiadat yang tumbuh, hidup dan berkembang di masyarakat hakikatnya merupakan refleksi daripada nilai-nilai agama Islam sesuai dengan hadih maja (falsafah hidup) rakyat Aceh "Hukom Ngon Adat Lage Zat Ngon Sifeut” bermakna bahwa antara adat dengan hukum adalah seperti zat dengan sifat, menjadi satu dan tidak boleh dipisahkan (Sanusi M. Syarif, 2005: 63). Atas dasar itu, pemegang kekuasaan adat dan politik (Sultan Imam Malikul Adil) pemerintahan di masa lalu dengan pemegang kekuasaan hukum (Qadli Malikul Adil) haruslah bekerjasama.

Berpegang pada prinsip di atas, maka kerajaan Aceh di masa itu juga membuat kategori adat itu pada tiga hal, yaitu (Ali Hasymy, 1989: 84).

a. Adatullah, yaitu hukum dari Allah

b. Adat Mahkamah, yaitu adat yang disusun oleh majelis kerajaaan. Contoh adat ini seperti adat blang, adat laot, adat gle, adat peukan, adat kuala, adat seuneubok, dan sebagainya.

c. Adat tunaih, adat ini berlaku di masingmasing daerah. Biasanya disusun secara musyawarah oleh Panglima Sagoe, Uleebalang, dan utusan masyarakat untuk menunjang hukum dan adat raja (adat mahkamah).

Selain tiga jenis adat di atas, ada beberapa ketentuan hukum dan adat yang tidak dapat diberikan keputusan oleh majelis ulama dan uleebalang, masyarakat boleh meminta 
ketetapan hukum dan adat pada Pengadilan Tinggi Syaikhul Islam dan Majelis Tinggi yang diketuai oleh Sri Baginda sendiri dan ditempatkan di Balai Baiturrahman (Ali Hasymy, 1989: 84).

Maksud hukum dalam hadih maja tersebut yaitu hukum Islam, karena Undang Undang Dasar Kerajaan Aceh ketika itu yang bernama Qanun Adat Meukuta Alam menegaskan bahwa hukum yang berlaku dalam Kerajaan Aceh Darussalam adalah Hukum Islam dengan sumber hukumnya Al-Qur'an, Al-Hadits, Alljma', dan Al-Qiyas (Ali Muhammad Rusydi, 2003: 186). Nyatalah bahwa Hadih Maja (falsafah hidup) tersebut adalah falsafah kehidupan rakyat Aceh dan Kerajaan Aceh Darussalam dan telah menjadi ketentuan pasti sebagai Jalan Hidup (way of life) dari rakyat Aceh.

Meskipun para ahli sejarah masih berselisih pendapat tentang masuknya Islam di Aceh, namun menurut Seminar Internasional tentang Islam di Asia Tenggara yang dilaksakan di Jakarta pada tanggal 15-18 November 1982 semua ahli mengatakan bahwa Islam pertama masuk ke wilayah nusantara adalah melalui Samudra Pasai Aceh dan Aceh mulai di kenal sejak agama Islam menjadi bagian dari kepercayaan dan keyakinan masyarakat Aceh (Taqwaddin, 2009: 42). Masuknya agama Islam ke Kerajaan Aceh Darussalam di bawah pimpinan Sultan Ali Mughayat Syah pada tahun 1511 - $1530 \mathrm{M}$ juga sangat mempengaruhi proses terbentuknya hukum adat (Ali Muhammad Rusydi, 2003: 147). Masuknya agama Islam ke wilayah Aceh telah memberi pengaruh besar dalam membentuk perilaku budaya masyarakat Aceh dalam membangun kesejahteraannya (Ali Muhammad, Rusydi, 2003: 147).

Penyebaran agama Islam pada masa itu berkembang luas dan cepat karena agama Islam sangat cocok dengan karakteristik masyarakat Aceh. Maka atas hasil mufakat pembesar-pembesar kerajaan, terbentuklah suatu sistem hukum adat yang mulai diberlakukan di Kerajaan Aceh Darussalam yang dalam pelaksanaannya berjalan tertib karena adanya kerjasama yang solid antara pemerintah, lembaga adat dan masyarakat (Ali Muhammad Rusydi, 2003: 147).

Ketika Sultan Iskandar Muda memimpin Kerajaan Aceh dalam rentang tahun 1607-1636, Aceh mengalami kemajuan yang sangat pesat dalam berbagai aspek kehidupan. Salah satunya termasuk aspek penataan hukum adat (Moehammad Hoesin, 1970: 54). Hukum adat Aceh sangat dikenal di hampir sebagian besar penjuru dunia khusunya di wilayah eropa daratan seperti Belanda maupun diluar eropa dartan seperti Inggris, Pertugis, termasuk di wilayah timur tengah seperti Turki, arab, Gujarat dan India termasuk juga di kawasan Asia Tenggara seperti Jepang, Vietnam, Thailand, Kamboja Malaysia, Filipina dan lainya (Husni Bahri Tob, 2003: 43).

Ada beberapa faktor yang menyebabkan adat Aceh yang kemudian dikenal dengan hukum adat di masa kejayaan Kerajaan Sultan Iskandar Muda dikenal serta dikagumi oleh hampir di sebagian besar negara-negara di dunia, yaitu (Rusdi Sufi, 2002: 58).

a. Hubungan diplomatis yang sangat erat dengan pemerintah Turki. Hasil hubungan bilateral ini Sultan sering berbagi pengalaman tentang kondisi kemajuan di Aceh, termasuk adat-istiadatnya;

b. Luasnya daerah yang berhasil ditaklukkan oleh Kerajaan Aceh. Daerah yang berhasil ditaklukkan sebagian besar adalah daerahdaerah Melayu. Misi Sultan adalah menyebarluaskan agama Islam dan juga memperkenalkan adat-istiadat Aceh. Secara tidak langsung, daerah yang berhasil ditaklukkan harus mengikuti aturan Kerajaan Aceh.

Oleh karenanya, menurut Ali Hasjmy sebenarnya ada tiga cara nilai-nilai Islam dalam membangun kebudayaan masyarakat baik di dunia maupun di Aceh, yaitu (Badruzzaman, 2007: 26):

1) meng-Islamkan kebudayaan yang telah ada;

2) menghapus sama sekali budaya yang telah ada, yaitu budaya yang bertentangan dengan aqidah dan ibadah;

3) membangun kebudayaan yang baru sepenuhnya.

Kepiawaian Sultan Iskandar Muda juga tergambar jelas ketika berhasil mempersatukan beberapa suku yang masih menganut adat budaya masing-masing menjadi adat nasional (hukum adat yang dikendalikan oleh kerajaan) (Van't Veer, Paul, 1977: 35). Sebelum Sultan Iskandar Muda memimpin, di Aceh tersebar empat suku besar, yaitu (Masri Singarimbun et.al, 1985: 91):

1) Suku Lhee Reutoh (Tiga ratus), yang berasal dari orang-orang mante dan Karo/ Batak; 
2) Suku Imuem Peut (Imam Empat), yang berasal dari orang-orang Hindu;

3) Suku Tok Batee, kaum asing yang berasal dari Arab, Parsi, Turki, dan Hindi yang sudah lama menetap di Aceh;

4) Suku Ja Sandang, yaitu kaum Hindu, tukang tuak yang pertama sekali datang ke Lampanaih.

Keempat suku ini saling mengklaim bahwa budaya mereka adalah yang terbaik di antara suku-suku lain. Sultan-sultan sebelumnya sangat sulit mempersatukan keanekaragaman adat masing-masing suku, sehingga karenanya masa tersebut dalam sejarah juga sering disebut adat plakpleung yaitu adat yang beranekaragam (Van't Veer, Paul, 1977: 47). Kejadian ini hampir sama seperti negara Indonesia yang terdiri dari ratusan suku. Kemudian atas beberapa nasehat dari mufti kerajaan dan ahli-ahli agama, maka Sultan telah dapat menyatukan suku-suku yang berbeda tersebut dalam satu wadah pemerintahan (Van't Veer, Paul, 1977: 47). Sehingga munculah hadih maja (falsafah hidup) yang masih dikenal sampai sekarang, yaitu: adat bak Poteu Meureuhom, hukom bak Syiah Kuala, kanun bak Putroe Phang, reusam bak Laksamana, hukom ngon adat lage zat ngon sifeut. Adapun penjelasannya dari istilah di atas, yaitu (Hakim Nyak Pha, 2001: 52).

a) Sultan Imam Malikul Adil sebagai kepala pemerintahan adalah pemegang kekuasaan politik dan adat negeri, atau pemegang kekuasaan eksekutif.

b) Qadli Malikul Adil (ulama) sebagai ketua mahkamah agung adalah pemegang kekuasaan hukum (yudikatif).

c) Rakyat adalah pemegang kekuasaan pembuatan undang-undang (legislatif) yang dalam hadih maja ini dilambangkan sebagai Putroe Phang, yaitu Puteri Pahang (permaisuri Sultan Iskandar Muda) yang mempelopori pembentukan Majelis Mahkamah Musyawarah Rakyat.

d) Pada waktu negara dalam keadaan bahaya/perang, pemegang segala kekuasaan dalam negara adalah Panglima Tertinggi Angkatan Perang, yang dalam istilah $h$ adih maja ini disebut sebagai Laksamana, yaitu Wazirul Harb.

Selain itu, berdasarkan Hadih Maja (falsafah hidup) yaitu "Adat bak Poteu Meureuhom, Hukom bak Syiah Kuala, Qanun bak Putroe Phang, Reusam bak Laksamana" maka dapat disimpulkan bahwa Hadih Maja (Falsafah

52 Yustisia Vol.1 No. 3 September-Desember 2012 hidup) tersebut mengandung makna simbolis ata $u$ perlambang mengenai isi dan pelaksanaan adat Aceh, yaitu (Badruzzaman, 2007: 39).

(1) Dilihat dari sudut politik pemerintahan, hadih maja menunjuk kepada perlambangan pembagian kekuasaan: eksekutif, legislatif, yudikatif serta perlambang kearifan dan kebijaksanaan pelaksana adat.

(2) Dilihat dari nama-nama yang tercantum dalam hadih maja maka makna simbolisnya adalah:

(a) Potoe Meureuhom merupakan lambang kekuasaan eksekutif dan kebesaran tanah Aceh;

(b) Syiah Kuala merupakan perlambangan Ulama sebagai pemegang kekuasaan yudikatif;

(c) Putroe Phang merupakan perlambangan cendekiawan pemegang kekuasaan legislatif;

(d) Laksamana/Bentara merupakan perlambangan dan kearifan dalam mengatur keragaman adat kebiasaan yang terdapat dalam masyarakat.

(3) Dilihat dari produk adat maka hadih maja tersebut menunjukkan ada empat macam adat Aceh yaitu:

(a) Adat Mahkota (Adat Meukuta Alam), yaitu produk adat yang berlaku umum untuk seluruh masyarakat Aceh (kerajaan) yang telah melalui proses inventarisasi Adat Reusam, penentuan peraturan pelaksanaannya (Qanun);

(b) Adat Tunnah, yaitu produk adat yang telah ditentukan hukum Islam yamg menjiwainya;

(c) Adat Mahkamah, yaitu produk adat yang telah diatur ketentuan pelaksanaannya (Qanun);

(d) Adat Reusam, yaitu produk adat yang berupa berbagai keragaman adat yang terdapat dan berlaku di daerah setempat di seluruh Aceh.

\section{Eksistensi Masyarakat Hukum Adat dan Lembaga-Lembaga Adat di Aceh}

a. Eksistensi Masyarakat Hukum Adat di Aceh

Isu masyarakat hukum adat populer secara internasional berawal dari gerakan protes masyarakat asli (native peoples) di Amerika Utara, yang meminta keadilan pembangunan akibat kehadiran sejumlah 
perusahaan transnasional di bidang pertambangan yang beroperasi di wilayah mereka. Gerakan protes tersebut mendapat respon positif Organisasi Buruh Internasional (International Labour Organisation) pada tahun 1950-an dalam upaya melindungi tenaga kerja. Melalui lembaga ini (ILO), istilah masyarakat adat dipopulerkan dengan sebutan indigenous peoples sebagai isu global di lembagalembaga PBB. Pada tahun 1989, ILO memperbaharui Konvensi tentang Perlindungan dan Integrasi Penduduk Asli dan Masyarakat Suku tersebut menjadi Konvensi Nomor 169 (Azmi Siradjudin, 2004.). Sekarang, istilah indigenous people semakin resmi penggunaannya dengan lahirnya Deklarasi PBB tentang Hak-hak Masyarakat Adat (United Nation Declaration on the Rights of Indigenous People) pada tahun 2007 (Yance Arizona, 2008).

Di Indonesia, istilah indigenous peoples diterjemahkan dengan "masyarakat adat", yang pada tahun 1993, disepakati sebagai suatu istilah pengganti sebutan yang beragam. Selanjutnya, sebagaimana ditetapkan dalam Kongres Masyarakat Adat Nusantara (KMAN) pertama yang diselenggarakan pada bulan Maret 1999, disepakati bahwa masyarakat adat adalah kelompok masyarakat yang memiliki asal usul leluhur (secara turun-temurun) di wilayah geografis tertentu, serta memiliki sistem nilai, ideologi, ekonomi, politik, budaya, sosial dan wilayah sendiri (Keputusan Kongres Masyarakat Adat Nusantara No. 01/KMAN/1999). Sementara dalam redaksinya yang lain, Prof. T. Djuned, mengemukakan beberapa karakteristik masyarakat adat, yaitu ( $\mathrm{T}$. Djuned, 2003: 49):

1) menjalankan sistem pemerintahan sendiri;

2) menguasai dan mengelola sumber daya alam dalam wilayahnya terutama untuk kemanfaatan warganya;

3) bertindak ke dalam mengatur dan mengurus warga serta lingkungannya. Ke luar bertindak atas nama persekutuan sebagai badan hukum;

4) hak ikut serta dalam setiap transaksi yang menyangkut lingkungannya;

5) hak membentuk adat;

6) hak menyelenggarakan sejenis peradilan.
Di Indonesia, masyarakat adat telah ada beratus-ratus tahun yang lalu, jauh sebelum lahirnya negara ini. Mereka telah memiliki sistem kebudayaan yang kompleks dalam tatanan kemasyarakatannya. Indonesia seharusnya merasa beruntung dengan adanya masyarakatmasyarakat adat yang jumlahnya lebih dari seribu komunitas. Keberadaan mereka merupakan suatu kekayaan bangsa, karena ada lebih dari seribu ragam ilmu pengetahuan yang telah mereka kembangkan. Ada lebih seribu bahasa yang telah dimanfaatkan dan dapat membantu pengembangan khasanah Bahasa Indonesia dan masih banyak lagi hal-hal lain yang mereka sumbangkan (Sandra Moniaga, 2002: 73).

Di dalam kehidupan sosial masyarakat Aceh terdapat beberapa kelompok etnik/adat dengan identitas dan keberadaan sesuai sejarah keturunan, wilayah, dialek bahasa, sosial budaya, dan hukum-hukum tradisional. Setiap kelompok ini merupakan kelompok otonom dan independen dalam mengatur komunitas-nya sebagaimana halnya dalam pengelo-laan sumber daya alam. Unit terkecil dari kelompok masyarakat adat ini disebut gampông (kampong setara dengan desa). Setiap gampông dikepalai oleh seorang Keuchik atau Geuchik (kepala desa). Setiap gampông ada sebuah meunasah yang dipimpin oleh seorang Imum Meunasah. Beberapa gampông akan tergabung dalam unit yang lebih besar yang disebut Mukim. Setiap Mukim dikepalai oleh seorang Imuem Mukim. Pada zaman dahulu mukim dipimpin oleh seorang Ulee Balang, yaitu Panglima Kesultanan. Dalam tingkat gampông dan mukim ini terdapat institusi adat yang berperan dalam kehidupan sosial budaya, ekonomi, dan politik di masyarakat. Di samping itu, juga terdapat hukum adat yang otonom di setiap unit wilayah.

Sejak dikeluarkannya Undang Undang Nomor 5 Tahun 1979, struktur pemerintahan mukim mulai tersingkir, namun peran mukim di desa-desa seluruh Aceh tetap masih berjalan. Hal ini terlihat dengan masih terdapatnya Imum Mukim di desa tersebut yang berperan dalam memecahkan berbagai persoalan di gampông-gampông. 
Persoalan mukim pada akhirnya diakui juga oleh pemerintah dengan dimuatnya dalam Undang Undang Pemerintahan Aceh Nomor 11 Tahun 2006. Dijelaskan bahwa mukim sudah termasuk ke dalam struktur pemerintahan Aceh. Imum Mukim sebagai kepala pemerintahan tingkat mukim berperan sebagai jembatan antara pemerintahan dengan adat yang berlaku dalam masyarakat setempat. Dalam konteks penataan ruang, mukim harus dijadikan sebagai unit terkecil pada perencanaan penataan ruang/wilayah.

Berdasarkan fakta sejarah, sangatlah beralasan apabila kemudian Snouck Hugronje berpendapat bahwa pembagian kewilayahan dalam bentuk mukim telah mapan di Aceh dan dengan cara yang seragam, baik di kawasan Aceh Rayeuk maupun di kenegerian-kenegerian di luarnya (Masri Singarimbun.et.al, 1985: 90-91). Oleh karenanya, Zainuddin H.M menyatakan bahwa mukim merupa-kan Atjehche Organisasi atau sebuah organisasi khas Aceh (Zainuddin , 1961: 317).

Meskipun secara juridis lembaga pemerintahan mukim baru diakui kembali keberadaannya sejak tahun 2001 setelah diberlakukannya Undang Undang tentang Otonomi Khusus Nanggroe Aceh Darussalam, atau tepatnya pada tahun 2003 setelah diundangkannya Qanun NAD tentang Pemerintahan Mukim. Namun Secara de facto, keberadaan mukim masih cukup eksis dan diakui di seluruh Nanggroe Aceh, sekalipun antara warga masyarakat Aceh terdapat beragam suku dan kultur yang berbeda (T. Djuned (et.al), 2003: 38).

Suatu masyarakat agar dapat dikatakan sebagai masyarakat hukum adat (rechtgemeinschaap), haruslah terpenuhi beberapa syarat sebagaimana sering dikemukakan oleh para ahli dan kemudian ditegaskan pula dalam peraturan perundang-undangan. Syarat dimaksud menurut Penjelasan Pasal 67 Undang Undang Nomor 41 Tahun 1999 tentang Kehutanan, adalah:

1) masyarakatnya masih dalam bentuk paguyuban (rechsgemeenschap);

2) terdapat kelembagaan dalam bentuk perangkat penguasa adatnya;

3) terdapat wilayah hukum adat yang jelas;
4) terdapat pranata hukum, khususnya peradilan adat yang masih ditaati; dan

5) masih mengadakan pemungutan hasil hutan di wilayah hutan sekitarnya untuk pemenuhan kebutuhan hidup sehari-hari.

Menurut hemat penulis, semua persyaratan di atas dapat ditemukan dalam kehidupan sehari-hari di gamponggampong (desa-desa) di dalam kehidupan masyarakat Aceh. Adapun analisis dan pembuktiannya sebagai berikut.

Pertama, sebagian besar warga gampong masih memiliki ikatan geneologis dengan sesamanya. Dengan demikian, kepedulian dan kebersamaan di gampong dan juga di dalam suatu kemukiman terutama yang bermukim bukan di perkotaan saling keterikatan bukan hanya dikarenakan solidaritas territorial, tetapi memang merasa sekaum seketurunan (gemeenschap). Warga gampong masih memiliki perasaan bersalah atau berdosa jika tidak melayat ke rumah warga gampong kita yang tertimpa musibah. Begitu pula jika ada tetangga yang melakukan hajatan (meukereuja), para warga gampong sejak malam hari hingga selesainya khanduri tersebut terus membantu dengan segala upaya agar acara dimaksud sukses dengan tiada kekurangan sesuatu apapun. Bahkan, seringkali pula pihak yang melakukan hajatan melimpahkan sepenuhnya penyelenggaraan khanduri tersebut pada geusyiek, selaku kepala gampong. Hal tersebut menunjukkan bahwa kehidupan masyarakat mukim atau gampong di Aceh yang masih gemeenschap, bukan gesselschap.

Kedua, di dalam kehidupan kemuki-man di Aceh masih ditemukan adanya lembaga-lembaga adat beserta perangkat penguasa adatnya (Taqwaddin, 2009:

49). Sampai saat ini masih ditemukan eksisnya kelembagaan adat di Aceh dengan susunan sebagai berikut.

(1) Lembaga pemerintahan mukim yang diketuai oleh imeum mukim.

(2) Lembaga keagamaan yang dipimpin oleh imeum meseujid.

(3) Lembaga musyawarah mukim yang dipimpin oleh tuha lapan.

(4) Lembaga pemerintahan gampong dipimpin oleh geusyiek. 
(5) Lembaga keagamaan di gampong dipimpin oleh imeum meunasah, dan

(6) Lembaga musyawarah gampong oleh tuha peut.

(7) Lembaga adat persawahan yang dipimpin oleh kejruen blang.

(8) Lembaga adat laot yang dipimpin oleh panglima laoet.

(9) Lembaga adat perkebunan yang dipimpin oleh peutua sineboek.

(10) Lembaga adat hutan yang dipimpin oleh panglima uteun atau pawang glee.

(11) Lembaga adat lalulintas laut yang dipimpin oleh syahbanda.

(12) Lembaga adat perdagangan yang dipimpin oleh haria peukan.

Keberadaan lembaga adat di suatu kemukiman bergantung pada letak geografi kemukiman tersebut, sehingga, dapat terjadi, pada suatu kemukiman ada lembaga adat yang tidak ada pada kemukiman lainnya. Misalnya, lembaga adat laothanya ada pada kemukiman yang wilayahnya di pesisir laut. Begitu pula lembaga adat hutan hanya ada pada kemukiman yang memiliki wilayah hutan. Namun ada pula kemukiman yang memiliki lembaga adat hutan dan juga lembaga adat laut, jika di kemukiman tersebut terdapat wilayah laut dan gunung.

Ketiga, ada wilayah hukum adat yang jelas. Suatu kemukiman adalah suatu juridiksi territorial yang jelas dan tegas dalam masyarakat Aceh. Artinya, jelas wilayah dan batas-batasnya. Hanya saja, seringkali batas-batas tersebut tidak tersurat di dalam suatu naskah tertulis tetapi hanya berupa batas-batas alam yang mengacu pada penuturan para nenek moyang (endatu) terdahulu. Batas ini dapat berupa: sungai (krueng), tebing (tereubeng), alur (alue), lorong (juroeng), pematang (ateung), parit (lueng), dan lain-lain.

Keempat, masih adanya peradilan adat. Pada masa Kerajaan Aceh sampai awal kemerdekaan, dan juga akhir-akhir ini, kecuali Era Orde Baru, di gamponggampong dan juga di kemukiman memiliki sistem musyawarah penyelesaian sengketa. Padamasa Sultan Iskandar Muda, "perkara-perkara kecil biasanya diselesaikan oleh keuciek dengan tengku meunasahyang dibantu oleh tuha peut. Tanpa vonis, maksudnya, tanpa kalah menang persengketaan itu diselesaikan secara damai yang disebut dengan hukum peujroh (hukum kebaikan). Dengan demikian, dari aspek historis, sejak dahulu kala gampong telah memiliki kewenangan untuk menyelesaikan perkara-perkara kecil, penjurian kecil, perkelahian, perkara-perkara sipil yang kecil-kecil yang nilai perkaranya tidak lebih dari 100 ringgit, dan lain-lain (Taqwaddin, 2009: 38). Dengan berlakunya Undang Undang Nomor 11 Tahun 2006 tentang Pemerintahan Aceh, telah mulai lagi dilakukan penyelesaian perkara secara adat di gampong-gampong dan bahkan sampai pada tingkat kemukiman (Taqwaddin, 2008: 42). Kini malah sistem penyelesaian sengketa secara adat telah mendapat pengaturannya yang cukup tepat di dalam satu bab tersendiri pada Qanun Aceh Nomor 9 Tahun 2008 tentang Pembinaan Adat.

Kelima, masyarakat hukum adat mengadakan pemungutan hasil hutan di wilayah hutan sekitarnya untuk pemenuhan kebutuhan hidup sehari-hari. Menurut penulis, syarat ini masih terpenuhi di dalam masyarakat Aceh. Masih banyak warga gampong yang menggantungkan hidupnya pada hutan dengan memungut hasil hutan sebagai mata pencahariannya. Meu glee, meu awe, meu rusa, meu uno, dan lain-lain adalah kegiatan pemungutan hasil hutan di Aceh yang dilaksanakan dengan segala kearifan tradisional. Bahkan pemungutan hasil hutan berupa kayu pun lazim dilakukan oleh warga gampong yang berdomisili di sekitar hutan. Hanya saja dengan dikeluarkan Instruksi Gubernur Nomor 5 Tahun 2007 tentang Moratorium Logging, kegiatan ini banyak menimbulkan masalah saat ini.

Terpenuhinya kelima syarat sebagaimana dimaksud oleh Undang Undang Nomor 41 Tahun 1999 tentang Kehutanan, yang kemudian juga dinyataan dalam Qanun NAD Nomor 4 Tahun 2003 tentang Pemerintahan Mukim, maka jelaslah bahwa pemerintahan mukim di Aceh merupakan masyarakat hukum adat Aceh (Taqwaddin, 2009: 270). Sehubungan hal tersebut, maka mukim sebagai persekutuan masyarakat hukum adat memiliki kewenangan dan hak asal usul, berupa (T. Djuned, 2003: 31): 
(a) menjalankan sistem pemerintahan sendiri;

(b) menguasai dan mengelola sumber daya alam dalam wilayahnya terutama untuk kemanfaatan warganya;

(c) bertindak ke dalam mengatur dan mengurus warga serta lingkungannya. Ke luar bertindak atas nama persekutuan sebagai badan hukum;

(d) hak ikut serta dalam setiap transaksi yang menyangkut lingkungannya;

(e) hak membentuk adat;

(f) hak menyelenggarakan sejenis peradilan.

\section{b. Eksistensi Lembaga-lembaga Adat di} Aceh

Terkait kelembagaan adat, melalui Pasal 1 ayat (5) Peraturan Daerah (Perda) Nomor 7 Tahun 2000 tentang Penyelenggaraan Kehidupan Adat, diulas seputar lembaga adat, yang menyebutkan bahwa: "Lembaga Adat adalah suatu organisasi kemasyarakatan adat yang dibentuk oleh suatu masyarakat hukum adat tertentu, mempunyai wilayah tertentu dan harta kekayaan sendiri serta berhak dan berwenang untuk mengatur dan mengurus serta menyelesaikan hal-hal yang berkaitan dengan adat Aceh". Selain itu, definisi lembaga adat juga diberikan dalam Qanun Aceh Nomor 10 Tahun 2008 tentang Lembaga Adat, Bab I Ketentuan Umum, tepatnya Pasal 1 angka 9 yang hakekatnya memberikan rumusan definisi yang sama sebagaimana dirumuskan Pasal 1 ayat (5) Peraturan Daerah (Perda) Nomor 7 Tahun 2000 tersebut diatas.

Selanjutnya, keberadaan lembagalembaga adat secara umum pada hakikatnya dibangun oleh tiga elemen atau unsur utama baik yang bersifat supra struktur maupun infra struktur yaitu (Muhammad Hakim Nyak Pha, 2001: 48).

1) Organisasi Desa

Desa ialah suatu kesatuan kemasyarakatan berdasarkan ketunggalan wilayah yang organisasinya didasarkan atas tradisi yang hidup dalam suasana rakyat dan mempunyai suatu badan tata urusan pusat yang berwibawa di seluruh lingkungan wilayahnya. la merupakan kesatuan bertunggal wilayah terbesar dalam suasana rakyat dan merupakan organisasi pemerintahan. Desa dapat dibagi atas tiga jenis berikut ini. (Taqwaddin, 2009: 37):

a) Desa bersentralisasi, yaitu organisasi desa yang sederhana, wilayahnya tidak terbagi-bagi, sehingga segala kepentingan rumah tangga seluruh wilayahnya diselenggarakan oleh suatu badan tata urusan pusat yang merupakan satu-satunya badan tata urusan yang berwibawa di seluruh wilayahnya. Contohnya desa di Jawa, Madura dan Bali.

b) Desa berdesentralisasi, yaitu desa yang luas wilayahnya, terbagi atas wilayah lebih kecil, yang masing-masing dalam batas otonomi tertentu dalam mengurus kepentingan dalam rumah tangganya sendiri. Di samping suatu badan tataurusan pusat yang berwibawa di seluruh wilayah desa, ada jua badanbadan tata urusan setempat yang berwibawa dalam bagian masingmasing. Ini bertujuan untuk mengurus dan mengatur rumah tangganya dan memiliki kewibawaannya selaku amanat dari badan tata urusan pusatnya. Contoh di wilayah Angkola dan Mandailing.

c) Serikat Desa-desa, yaitu desa yang letaknya berbatasan, mungkin mengadakan persetujuan bersama untuk menggabungkan beberapa jenis kepentingan bersama seperti kepentingan pengairan, lalu lintas, dan lainnya.

Oleh karena itu, desa memiliki fungsi dan konsekuensi yang penting dalam hukum adat, yaitu :

a) merupakan subyek hak purba atas tanah yang merupakan wilayahnya;

b) merupakan masyarakat dan badan hukum yang berwibawa dalam perkembangan dan pemeliharaan Hukum Adat.

2) Ketunggalan Silsalah

Dalam menyelidiki ketunggalan silsilah maka perlu diperhatikan, yaitu:

a) dihitung satu orang leluhur yaitu sang pemuka menjadi peletak dasar garis keturunan; 
b) dihitung dari seorang terkemuka tanpa pembatasan berapa generasi jauhnya;

c) diperhitungkan suatu rantai keturunan istimewa;

d) mungkin juga dihitung melalui garis yang tidak berketentuan.

3) Paguyuban Hidup

Paguyuban hidup bermakna suatu himpunan, kumpulan, maupun kelompok dari suatu komunitas manusia yang dalam interaksi sosial satu dengan lainnya selain memiliki ikatan kebatinan yang kuat dengan perasaan satu kaum juga memiliki katakter yang khas dan menonjol sehingga menjadi suatu identitas kolektif dan manunggal.

Lembaga-lembaga adat di Aceh yang hidup dan berkembang secara kultur, historis, dan sosiologis penuh dengan tantangan global dan distorsi sebagai krisis social, budaya, ekonomi, dan politik, pada umumnya dapat diklasifikasikan dalam dua kelompok, yaitu (T. Djuned, 2003: 38):

1) Kelompok lembaga adat tradisional, seperti kawasan Mukim, kawasan Gampong, kawasan Laot, kawasan Blang (persawahan), kawasan pelabuhan (kesyahbandaran), dan kawasan-kawasan kecil lainnya. Penanganan/pengelolaan kelompokkelompok dimaksud dilakukan oleh lembaga-lembaga fungsional (fungsionaris adat), seperti Imuem Mukim, Keuchik, Imuem Meunasah, Imuem Chik, Tuha Peut, Tuha Lapan, Panglima Laot, Keujruen Blang, Peutua Seuneubok, Haria Peukan, Syahbanda dan fungsi-fungsi lainnya dalam bentuk yang lebih kecil.

2) Kelompok lembaga adat formal (semi pemerintahan). Kelompok lembagalembaga ini sesuai dengan sosiologis kehidupan masyarakat dalam konteks sinkronisasi dengan kebijakan tugas-tugas pemerintahan, maka atas legalisasi pemerintah pusat/ daerah dibentuklah lembaga-lembaga adat dengan Surat Keputusan Gubernur Kepala daerah Istimewa Aceh.

Keberadaan masyarakat hukum adat dan lembaga adat dengan kepekaan dan sensitifitas kearifan lokal yang dimilikinya telah menempatkannya menjadi salah satu alternatif dalam mekanisme penyelesaian berbagai persoalan yang terjadi di masyarakat (Taqwaddin, 2009:

32). Lembaga adat yang berkembang dalam kehidupan masyarakat Aceh sejak dahulu hingga sekarang mempunyai fungsi dan berperan dalam membina nilainilai budaya, norma-norma adat dan aturan untuk mewujudkan keamanan, keharmonisasian, ketertiban, ketentraman, kerukunan dan kesejahteraan bagi masyarakat Aceh sebagai manifestasi untuk mewujudkan tujuan-tujuan bersama sesuai dengan keinginan dan kepentingan masyarakat setempat.

Di Indonesia dan di Aceh khususnya, keberadaan hukum adat, masyarakat hukum adat beserta dengan lembaga adat telah mendapat pengakuan dan penghormatan dari negara secara resmi sebagaimana yang tertuang dalam hukum dasar Negara (grondwet) Republik Indonesia yaitu UUD Negara Republik Indonesia Tahun 1945, tepatnya dalam Pasal 18 B hasil amandemen dinyatakan sebagai berikut.

Ayat (1), Negara mengakui dan menghormati satuan-satuan pemerintahan daerah yang bersifat khusus atau bersifat istimewa yang diatur dengan undangundang.

Ayat (2), Negara mengakui dan menghormati kesatuan-kesatuan masyarakat hukum adat beserta hak-hak tradisionalnya sepanjang masih hidup dan sesuai dengan perkembangan masyarakat dan prinsip Negara Kesatuan Republik Indonesia, yang diatur dalam undangundang.

Selanjutnya dalam Pasal 28 I ayat (3) UUD 1945 ditegaskan bahwa "Identitas budaya dan hak masyarakat tradisional dihormati selaras dengan perkembangan jaman dan peradaban". Dengan demikian jelaslah bahwa Pasal $18 \mathrm{~B}$ ayat (1) dan (2), dan Pasal 28 I ayat (3) tersebut merupakan dasar legitimasi pengakuan masyarakat hukum adat yang ada di daerah, khususnya di Aceh untuk membentuk lembaga-lembaga daerah sebagai bentuk penjabaran lebih lanjut semangat konstitusi.

Selain itu, pengaturan mengenai masyarakat hukum adat dan lembaga adat diperkuat dengan adanya penjabaran lebih 
lanjut ke dalam beberapa Undang Undang, di antaranya dikeluarkannya Undang Undang Nomor 39 Tahun 1999 tentang Hak Asasi Manusia, yang Pasal 6 ayat (1) dan (2) menyatakan sebagai berikut.

(1) Dalam rangka penegakan hak asasi manusia, perbedaan dan kebutuhan dalam masyarakat hukum dapat harus diperhatikan dan dilindungi oleh hukum, masyarakat dan pemerintah.

(2) Identitas budaya masyarakat hukum adat, termasuk hak atas tanah ulayat dilindungi, selaras dengan perkembangan zaman.

Penjelasan Pasal 6 ayat (1) Undang Undang Nomor 39 Tahun 1999 (TLN No. 3886) menyebutkan bahwa: "Hak adat yang secara nyata masih berlaku dan dijunjung tinggi di dalam lingkungan masyarakat hukum adat harus dihormati dan dilindungi dalam rangka perlindungan dan penegakan Hak Asasi Manusia dalam masyarakat bersangkutan dengan memperhatikan hukum dan peraturan perundang-undangan". Selanjutnya, dalam bagian Penjelasan Pasal 6 ayat (2) dinyatakan bahwa: "Dalam rangka penegakan Hak Asasi Manusia, identitas budaya nasional masyarakat hukum adat yang masih secara nyata dipegang teguh oleh masyarakat hukum adat setempat, tetap dihormati dan dilindungi sepanjang tidak bertentangan dengan asas-asas negara hukum yang berintikan keadilan dan kesejahteraan masyarakat". Kehadiran Undang Undang Nomor 39 Tahun 1999 tersebut melengkapi dalam mengukuhkan keberadaan masyarakat hukum adat beserta kelembagaan adat yang ada di Indonesia, khususnya di Aceh.

Dalam konteks khusus kedaerahan Aceh, dasar hukum pengakuan dan penghormatan masyarakat hukum adat sekaligus pembentukan lembaga adat juga diatur lebih lanjut dalam Undang Undang Nomor 44 Tahun 1999 tentang Penyelenggaraan Keistimewaan Aceh sebagai manifestasi amanat Konstitusi, yang mana dalam Pasal 3 ayat (2) yang menyebutkan bahwa: "Penyelenggaraan Keistimewaan meliputi penyelenggaraan kehidupan beragama; penyelenggaraan kehidupan adat; penyelenggaraan pendidikan; dan peran ulama dalam penetapan kebijakan daerah.
Keistimewaan berkait penyelenggaraan kehidupan adat sebagaimana tersebut di atas merupakan dasar hukum bagi Pemerintah Aceh untuk menjabarkan lebih lanjut berbagai hal dalam penyelenggaraan kehidupan adat ke dalam bentuk berbagai produk hukum daerah berupa Qanun atau Peraturan Daerah (Perda). Melaui Undang Undang Nomor 44 Tahun 1999 tentang Keistimewaan Aceh tersebut, Pemerintah Aceh telah diberi wewenang oleh Pemerintah untuk melakukan dua hal sebagaimana yang diamanatkan dalam Pasal 6 dan Pasal 7, Bagian Ketiga mengenai Penyelenggaraan Kehidupan Adat menyebutkan bahwa sebagai berikut.

Pasal 6: Daerah dapat menetapkan berbagai kebijakan dalam upaya pemberdayaan, pelestarian, dan pengembangan adat serta lembaga adat di wilayahnya yang dijiwai dan sesuai degan syariat Islam.

Pasal 7: Daerah dapat membentuk lembaga adat dan mengakui lembaga adat yang sudah ada sesuai dengan kedudukannya masing-masing di Provinsi, Kabupaten/Kota, Kecamatan, Kemukiman, Desa atau Gampong.

Dalam rangka memperkuat sekaligus menindak lanjuti Undang Undang Nomor 44 Tahun 1999 tersebut, Pemerintah Aceh telah mengeluarkan Peraturan Daerah (Perda) Nomor 7 Tahun 2000 tentang Penyelenggaraan Kehidupan Adat. Selain itu, sebagai bentuk tindak lanjut dan kosistensi maka Pemerintah Aceh mengeluarkan Qanun Aceh Nomor 9 Tahun 2008 tentang Pembinaan Kehidupan Adat dan Adat Istiadat, dan Qanun Aceh Nomor 10 Tahun 2008 tentang Lembaga Adat.

Keberadaan lembaga-lembaga adat di Aceh pengaturannya terdapat dalam Pasal 98 ayat (3) Undang Undang Nomor 11 Tahun 2006 tentang Pemerintahan Aceh maupun Pasal 2 ayat (2) (Peraturan Daerah) Provinsi Nomor 10 Tahun 2008 tentang Lembaga Adat yang menempatkan struktur kelembagaan adat di Aceh ke dalam beberapa jenis dan hierarki yang sama meliputi: a. Majelis Adat Aceh (MAA); b. imeum mukim atau nama lain; c. imeum chik atau nama lain; $d$. keuchik atau nama lain; e. tuha peut atau nama lain; f. tuha lapan atau nama lain; g. imeum meunasah atau nama lain; $h$. keujreun 
blang atau nama lain; i. panglima laot atau nama lain; j. pawang glee atau nama lain; k. peutua seuneubok atau nama lain; I. haria peukan atau nama lain; dan $m$. syahbanda atau nama lain".

Berdasarkan ketentuan Pasal 98 ayat (3) Undang Undang Nomor 11 Tahun 2006 maupun berdasarkan Pasal 2 ayat (2) Qanun Aceh Nomor 10 Tahun 208 tentang Lembaga Adat, secara struktural telah menempatkan Majelis Adat Aceh (MAA) sebagai lembaga adat yang membawahi lembaga-lembaga adat lain seperti: Imuem mukim; Imuem chik; Keuchik; Tuha peuet; Tuha lapan; Imuem meunasah; Keujreun blang; Panglima laot; Pawang glee; Peutua seuneubok; Haria peukan; Syahbanda.

Dalam hal pembinaan kehidupan adat dan adat istiadat di Aceh dilakukan sesuai perkembangan keistimewaan dan kekhususan Aceh yang berlandaskan nilai-nilai syari'at Islam dan dilaksanakan oleh Wali Nanggroe sebagaimana yang diamanatkan dalam Pasal 99 ayat (1) Undang Undang Nomor 11 Tahun 2006 tentang Pemerintahan Aceh.

Kelembagaan Wali Nanggroe merupakan kepemimpinan adat sebagai pemersatu masyarakat yang independen, berwibawa, dan berwenang membina dan mengawasi penyeleng-garaan kehidupan lembaga-lembaga adat, adat istiadat, dan pemberian gelar/derajat dan upacaraupacara adat lainnya.

Dalam rangka memperkuat kedudukan dan daya berlakunya kelembagaan adat di Aceh, maka melalui Undang Undang Nomor 11 Tahun 2006 tentang Pemerintahan Aceh, pemerintah telah menempatkan gubernur dalam kedudukannya sebagai wakil pemerintah, yang memiliki tugas dan wewenang mengkoordinasikan lima hal, yang salah satunya adalah dalam pembinaan dalam penyelenggaraan kekhususan dan keistimewaan Aceh khususnya di bidang Adat istiadat sebagaimana yang diamanatkan Pasal 43 ayat (1).

Dengan demikian, jelaslah bahwa keberadaan (ekesistensi) kelembagaan adat selain telah mendapatkan pengakuan dan penghormatan secara yuridis formal, baik dalam skala nasional maupun lokal, juga telah menunjukkan eksistensinya melalui berbagai kiprah dalam melaksana- kan berbagai langkah penataan, pembinaan tata kehidupan masyarakat, termasuk dalam menyelesaikan permasalahan sosial yang timbul di masyarakat.

3. Tugas, Fungsi dan Wewenang LembagaLembaga Adat di Aceh dalam Rangka Penyelenggaraan Keistimewaan dan Otonomi Khusus di Aceh

Amanat Pasal 98 ayat (4) Undang-Undang Nomor 11 Tahun 2006 pada hakikatnya menghendaki pengaturan lebih lanjut seputar tugas, wewenang, hak dan kewajiban lembaga adat, pemberdayaan adat, dan pembinaan kehidupan adat istiadat ke dalam suatu bentuk Qanun (Peraturan Daerah) Provinsi Aceh. Dalam rangka menindaklanjuti hal tersebut, maka dikeluarkanlah dua Qanun yaitu, Qanun Aceh Nomor 9 Tahun 2008 tentang Pembinaan Kehidupan Adat dan Adat Istiadat dan Qanun Aceh Nomor 10 Tahun 2008 tentang Lembaga Adat.

Keberadaan kelembagaan adat di Aceh memiliki peran sangat strategis dan signifikan dalam melakukan penataan, penanaman, serta pengawasan terhadap tata prilaku masyarakat melalui para fungsionaris adat yang terkait (Kurniawan, 2010: 59). Lembaga-lembaga adat tersebut hakikatnya memiliki fungsi dan peran sebagai wahana partisipasi masyarakat dalam penyelenggaraan Pemerintahan Aceh dan Pemerintahan Kabupaten/Kota di bidang keamanan, ketenteraman, kerukunan, dan ketertiban masyarakat baik sebagaimana yang diamanatkan dalam Pasal 98 ayat (1) Undang Undang Nomor 11 Tahun 2006 maupun dalam Pasal 2 ayat (1) Qanun Aceh Nomor 10 Tahun 2008 tersebut.

Lembaga-lembaga adat yang ada di Aceh memiliki sejumlah kewenangan sebagaimana yang diamanatkan Pasal 4 Qanun (Peraturan Daerah Provinsi) Aceh Nomor 10 Tahun 2008 tentang Lembaga Adat yaitu:

a. menjaga keamanan, ketenteraman, kerukunan dan ketertiban masyarakat;

b. membantu pemerintah dalam pelaksanaan pembangunan;

c. mengembangkan dan mendorong partisipasi masyarakat;

d. menjaga eksistensi nilai-nilai adat dan adat istiadat yang tidak bertentangan dengan syariat Islam;

e. menerapkan ketentuan adat;

f. menyelesaikan masalah sosial kemasyarakatan; 
g. mendamaikan sengketa yang timbul dalam masyarakat;

h. menegakkan hukum adat.

Adapun tugas, fungsi dan wewenang lembaga-lembaga adat di Aceh, baik sebagaimana dimaksud Pasal 98 ayat (3) Undang Undang Nomor 11 Tahun 2006 tentang Pemerintahan Aceh maupun dalam Pasal 2 ayat (2) Qanun Aceh Nomor 10 Tahun 2008 tentang Lembaga Adat, adalah sebagai berikut.

a. Majelis Adat Aceh (MAA)

Majelis Adat Aceh yang selanjutnya disebut MAA merupakan sebuah majelis penyelenggara kehidupan adat di Aceh yang struktur kelembagaannya sampai tingkat gampong (desa) (Pasal 1 angka 10 Qanun Nomor 10 Tahun 2008 tentang lembaga Adat). MAA bertugas membantu Wali Nanggroe dalam membina, mengkoordinir lembaga-lembaga adat sebagaimana yang diamanatkan Pasal 7 ayat (1) Qanun Nomor 10 Tahun 2008 tentang Lembaga Adat. MAA memiliki struktur berjenjang untuk membina, mengkoordinir lembaga-lembaga adat yang ada di seluruh wilayah Aceh. Pengaturan jenjang struktural kelembagaan MAA diatur dalam Pasal 2 Qanun Nomor 3 Tahun 2004 tentang Pembentukan, Susunan Organisasi dan Tata Kerja (SOTK) MAA, Pembentukan dan Kedudukan MAA), yang terdiri atas:

1) MAA Propinsi dibentuk oleh gubernur berkedudukan di ibukota propinsi.

2) MAA Kabupaten/Kota dibentuk oleh bupati/walikota berkedudukan di ibukota kabupaten/kota.

3) MAA Perwakilan dibentuk oleh MAA Propinsi berkedudukan di tempat masyarakat Perwakilan berada.

4) MAA yang dibentuk oleh camat, karena di ibukota kecamatan dalam Propinsi Nanggroe Aceh Darussalam dapat dibentuk MAA oleh camat.

5) Majelis Adat Mukim dan Gampong dibentuk oleh bupati/walikota berkedudukan di mukim dan gampong masing-masing.

Selain itu, dalam menjalankan fungsinya, MAA sebagai lembaga adat yang membawahi lembaga-lembaga adat lainnya di Aceh mempunyai wewenang (Lihat Pasal 3 Qanun Aceh Nomor 3 Tahun 2004 tentang Pembentukan,
Susunan Organisasi dan Tata Kerja Majelis Adat Aceh,):

1) mengkaji dan menyusun rencana penyelenggaraan kehidupan adat;

2) membentuk dan mengukuhkan lembaga adat;

3) menyampaikan saran dan pendapat kepada Pemerintahan dalam kaitan penyelenggaraan kehidupan adat diminta maupun tidak diminta.

Dalam upaya memberdayakan kembali sendi-sendi hukum adat dalam urusan pemerintahan, maka lembaga adat khususnya MAA mempunyai fungsi sebagaimana telah diamanatkan dalam Pasal 5 Qanun Nomor 3 Tahun 2004 :

1) meningkatkan pemeliharaan, pembinaan dan menyebarluaskan adat istiadat dan hukum adat dalam masyarakat sebagai bagian yang tidak terpisahkan dari adat di Indonesia;

2) meningkatkan kemampuan tokoh adat yang profesional sesuai dengan keadaan dan kebutuhan masyarakat di daerah;

3) meningkatkan penyebarluasan adat Aceh ke dalam masyarakat melalui keureja udep dan keureja mate, penampilan kreativitas, dan media massa;

4) menyelenggarakan pembinaan dan pengembangan fungsi Peradilan Adat Gampong dan peradilan Adat Mukim;

5) mengawasi penyelenggaraan adat istiadat dan hukum adat supaya tetap sesuai dengan Syariat Islam;

6) peningkatan kerja sama dengan berbagai pihak, perorangan maupun badan-badan yang ada kaitannya dengan masalah adat Aceh khususnya, baik di dalam maupun di luar negeri, sejauh tidak bertentangan dengan agama, adat istiadat dan perundang-undangan yang berlaku;

7) menyusun risalah-risalah untuk menjadi pedoman tentang adat;

8) ikut serta dalam setiap penyelenggaraan Pekan Kebudayaan Aceh Provinsi dan Kabupaten/Kota;

(9) mengusahakan perwujudan maksud dan makna falsafah hidup dalam masyarakat sesuai dengan "Adat Bak Poteumeureuhom, Hukom Bak 
Syiah Kuala, Qanun Bak Putro

Phang, Reusam Bak Laksama".

b. Imeum Mukim atau Nama Lain

Imeum Mukim adalah kesatuan masyarakat hukum di bawah kecamatan yang terdiri atas gabungan beberapa gampong yang mempunyai batas wilayah tertentu yang dipimpin oleh Imeum mukim atau nama lain dan berkedudukan langsung di bawah camat (Pasal 1 angka 13 Qanun Aceh Nomor 10 Tahun 2008 tentang Lembaga Adat). Imeum Mukim atau nama lain memiliki tugas: 1) melakukan pembinaan masyarakat; 2) melaksanakan kegiatan adat istiadat; 3 ) menyelesaikan sengketa; 4) membantu peningkatan pelaksanaan syariat Islam; 5) membantu penyelenggaraan pemerintahan; dan f) membantu pelaksanaan pembangunan (Pasal 8 Qanun Aceh Nomor 10 Tahun 2008).

c. Imeum Chik atau Nama Lain

Berdasarkan rumusan Pasal 1 angka 16, Qanun Aceh Nomor 10 Tahun 2008 tentang Lembaga Adat, Imeum Chik atau nama lain adalah imeum masjid pada tingkat mukim yang memimpin kegiatan-kegiatan masyarakat di mukim yang berkaitan bidang agama Islam dan pelaksanaan syari'at Islam. Adapun tugas Imeum Chik atau nama lain sesuai amanat Pasal 11 Qanun Aceh Nomor 10 Tahun 2008 ialah a) mengkoordinasikan pelaksanaan keagamaan dan peningkatan peribadatan serta pelaksanaan Syari'at Islam dalam kehidupan masyarakat; b) mengurus, menyelenggarakan dan memimpin seluruh kegiatan yang berkenaan dengan pemeliharaan dan pemakmuran masjid; dan c) menjaga dan memelihara nilai-nilai adat, agar tidak bertentangan dengan Syari'at Islam.

d. Keuchik atau Nama Lain

Keuchik atau nama lain adalah kepala persekutuan masyarakat adat gampong yang bertugas menyelenggarakan pemerintahan gampong, melestarikan adat istiadat dan hukum adat, serta menjaga keamanan, kerukunan, ketentraman dan ketertiban masyarakat (Pasal 1 angka 17 Qanun Aceh Nomor 10 Tahun 2008 ). Adapun tugas Keuchik atau nama lain adalah: a) membina kehidupan beragama dan pelaksanaan Syari'at Islam dalam masyarakat; b) menjaga dan memelihara adat dan adat istiadat yang hidup dan berkembang dalam masyarakat; c) memimpin penyelenggaraan pemerintahan gampong; d) menggerakkan dan mendorong partisipasi masyarakat dalam membangun gampong; e) membina dan memajukan perekonomian masyarakat; f) memelihara kelestarian fungsi lingkungan hidup; g) memelihara keamanan, ketentraman dan ketertiban serta mencegah munculnya perbuatan maksiat dalam masyarakat; h) mengajukan rancangan qanun gampong kepada Tuha Peut Gampong atau nama lain untuk mendapatkan persetujuan; i) mengajukan rancangan anggaran pendapatan belanja gampong kepada tuha peut gampong atau nama lain untuk mendapatkan perse-tujuan; j) memimpin dan menyelesaikan masalah sosial kemasyarakatan; dan k) menjadi pendamai terhadap perselisihan antar penduduk dalam gampong (Pasal 15 ayat (1) Qanun Aceh Nomor 10 Tahun 2008).

e. Tuha Peut atau Nama Lain

Istilah Tuha Peut terdapat pada dua level pemerintahan di Aceh, yaitu Tuha Peut Gampong (level desa) dan Tuha Peut Mukim (level kecamatan). Berdasarkan rumusan Pasal 1 angka 18 dan 19 Qanun Aceh Nomor 10 Tahun 2008 tentang Lembaga Adat, Tuha Peut atau nama lain adalah unsur pemerintahan gampong yang berfungsi sebagai badan permusyawaratan gampong". Sementara "Tuha Peut Mukim atau nama lain adalah alat kelengkapan mukim yang berfungsi memberi pertimbangan kepada imeum mukim". Tuha Peut Gampong atau nama lain memiliki tugas yang tak kalah pentingnya dengan para fungsionaris adat lainnya, yaitu a) membahas dan menyetujui anggaran pendapatan dan belanja gampong atau nama lain; b) membahas dan menyetujui qanun gampong atau nama lain; c) mengawasi pelaksanaan pemerintahan gampong atau nama lain; d) menampung dan menyalurkan aspirasi masyarakat dalam penyelenggaraan pemerintahan dan pembangunan gampong atau nama lain; e) merumuskan kebijakan gampong atau nama lain bersama Keuchik atau nama lain; f) memberi nasehat dan pendapat kepada Keuchik atau nama lain baik diminta maupun tidak diminta; dan g) menyelesaikan sengketa yang timbul dalam masyarakat bersama pemangku adat (Pasal 18 Qanun Aceh Nomor 10 Tahun 2008). 
f. Tuha Lapan atau Nama Lain

Tuha Lapan atau nama lain adalah lembaga adat pada tingkat mukim dan gampong yang berfungsi membantu imeum mukim dan keuchik atau nama lain (Pasal 1 angka 20 Qanun Aceh Nomor 10 Tahun 2008 tentang Lembaga Adat). Ketentuan Tuha Lapan atau nama lain diatur dalam Pasal 21 ayat (1) Qanun Nomor 10 Tahun 2008, yang menyebutkan bahwa "Pada tingkat Gampong atau nama lain dan Mukim dapat dibentuk Tuha Lapan atau nama lain sesuai kebutuhan dan perkembangan masyarakat". Tuha Lapan atau nama lain dipilih melalui musyawarah Gampong atau nama lain atau musyawarah mukim (ayat 2). Tuha Lapan atau nama lain beranggotakan unsur Tuha Peut atau nama lain dan beberapa orang mewakili bidang keahlian sesuai dengan kebutuhan Gampong atau nama lain atau Mukim (ayat (3). Adapun pengangkatan dan pemberhentian Tuha Lapan atau nama lain serta tugas dan fungsinya ditetapkan dalam musyawarah gampong atau nama lain atau mukim (ayat 4).

g. Imeum Meunasah atau Nama Lain

Imeum Meunasah atau nama lain adalah orang yang memimpin kegiatankegiatan masyarakat di gampong yang berkenaan dengan bidang agama Islam, pelaksanaan, dan penegakan syari'at Islam (Pasal 1 angka 21 Qanun Aceh Nomor 10 Tahun 2008 tentang Lembaga Adat). Imeum Meunasah atau nama lain mempunyai tugas: a) memimpin, mengkoordinasikan kegiatan peribadatan, pendidikan serta pelaksanaan Syari'at Islam dalam kehidupan masyarakat; b) mengurus, menyelenggarakan dan memimpin seluruh kegiatan yang berkenaan dengan pemeliharaan dan pemakmuran meunasah atau nama lain; c) memberi nasehat dan pendapat kepada Keuchik atau nama lain baik diminta maupun tidak diminta; d) menyelesaikan sengketa yang timbul dalam masyarakat bersama pemangku adat; dan e). menjaga dan memelihara nilai-nilai adat, agar tidak bertentangan dengan Syari'at Islam (Pasal 23 Qanun Aceh Nomor 10 Tahun 2008).

h. Keujruen Blang atau Nama Lain

Keujruen Blang atau nama lain adalah orang yang memimpin dan mengatur kegiatan di bidang usaha persawahan (Pasal 1 angka 22 Qanun Aceh Nomor 10 Tahun 2008 tentang Lembaga Adat). Keujruen Blang atau nama lain mempunyai tugas : a) menentukan dan mengkoordinasikan tata cara turun ke sawah; b) mengatur pembagian air ke sawah petani; c) membantu pemerintah dalam bidang pertanian; d) mengkoordinasikan khanduri atau upacara lainnya yang berkaitan dengan adat dalam usaha pertanian sawah; e) memberi teguran atau sanksi kepada petani yang melanggar aturanaturan adat meugoe (bersawah) atau tidak melaksanakan kewajiban lain dalam sistem pelaksanaan pertanian sawah secara adat; dan f) menyelesaikan sengketa antar petani yang berkaitan dengan pelaksanaan usaha pertanian sawah (Pasal 25 Qanun Aceh Nomor 10 Tahun 2008).

i. Panglima Laot atau Nama Lain

Panglima Laot atau nama lain adalah orang yang memimpin dan mengatur adat istiadat di bidang pesisir dan kelautan (Pasal 1 angka 23 Qanun Aceh Nomor 10 Tahun 2008 tentang Lembaga Adat).

Dalam Pasal 27 ayat (1) Qanun Aceh Nomor 10 Tahun 2008 disebutkan bahwa lembaga Adat Panglima Laot atau nama lain terdiri atas tiga macam, yaitu:

1) Panglima Laot Lhok atau nama lain;

2) Panglima Laot kabupaten/kota atau nama lain; dan

3) Panglima Laot Aceh atau nama lain.

Panglima Laot Lhok atau nama lain, dipilih oleh pawang-pawang boat lhok atau nama lain masing-masing melalui musyawarah (Pasal 27 ayat 2). Selanjutnya Panglima Laot Kab/Kota atau nama lain dipilih dalam musyawarah Panglima Laot Lhok atau nama lain (Pasal 27 ayat 3). Kemudian Panglima Laot Aceh atau nama lain dipilih dalam musyawarah panglima laot kab/kota atau nama lain setiap 6 (enam) tahun sekali (Pasal 27 ayat 4). Panglima La'ot atau nama lain dalam melaksanakan tugas dan fungsinya berwenang (Pasal 28 ayat 1, Qanun Aceh Nomor 10 Tahun 2008):

(1) menentukan tata tertib penangkapan ikan atau meupayang termasuk menentukan bagi hasil dan hari-hari pantang melaut ; 
(2) menyelesaikan sengketa adat dan perselisihan yang terjadi di kalangan nelayan;

(3) menyelesaikan sengketa adat yang terjadi antar Panglima Laot Lhok atau nama lain; dan

(4) mengkoordinasikan pelaksanaan hukum adat laot, peningkatan sumber daya dan advokasi kebijakan bidang kelautan dan perikanan untuk peningkatan kesejahteraan nelayan.

Selain itu, sebagai salah satu perangkat dan fungsionaris adat di Aceh Panglima Laot atau nama lain memiliki tugas (Pasal 28 ayat (2) Qanun Nomor 10 Tahun 2008):

(1) melaksanakan, memelihara dan mengawasi pelaksanaan adat istiadat dan hukum adat laot;

(2) membantu Pemerintah dalam bidang perikanan dan kelautan;

(3) menyelesaikan sengketa dan perselisihan yang terjadi diantara nelayan sesuai dengan ketentuan hukum adat laot;

(4) menjaga dan melestarikan fungsi lingkungan kawasan pesisir dan laut;

(5) memperjuangkan peningkatan taraf hidup masyarakat nelayan; dan

(6) mencegah terjadinya penangkapan ikan secara illegal.

Panglima Laot Kabupaten/Kota sebagaimana disebutkan Pasal 28 ayat (3) memiliki tugas: (1) melaksanakan tugas-tugas sebagaimana dimaksud pada ayat (2) yang bersifat lintas Ihok atau nama lain; dan (2) menyelesaikan sengketa antar Panglima Laot Ihok atau nama lain.

Panglima Laot sebagai salah satu prangkat dan fungsionaris adat di Aceh, memiliki fungsi (Pasal 28 ayat (5) Qanun Nomor 10 Tahun 2008). :

(1) Panglima Laot Ihok atau nama lain dan Panglima Laot kab/kota atau nama lain sebagai ketua adat bagi masyarakat nelayan;

(2) Panglima Laot Ihok atau nama lain dan Panglima Laot kab/kota atau nama lain, sebagai penghubung antara pemerintah dan masyarakat nelayan; dan

(3) mitra Pemerintah dalam menyukseskan program pembangunan perikanan dan kelautan . j. Pawang Glee dan/atau Pawang Uteen atau Nama Lain

Pawang Glee dan/atau Pawang Uteun atau nama lain adalah orang yang memimpin dan mengatur adat-istiadat yang berkenaan dengan pengelolaan dan pelestarian lingkungan hutan (Pasal 1 angka 27 Qanun Aceh Nomor 10 Tahun 2008 tentang Lembaga Adat). Lembaga adat Pawang Glee atau nama lain dipilih oleh masyarakat kawasan hutan. Adapun tata cara pemilihan dan persyaratan Pawang Glee atau nama lain ditetapkan melalui musyawarah masyarakat kawasan hutan setiap 6 (enam) tahun sekali sebagaimana disebut dalam Pasal 30 ayat (1) dan ayat (2). Pawang Glee atau nama lain memiliki tugas : a) memimpin dan mengatur adat-istiadat yang berkenaan dengan pengelolaan dan pelestarian lingkungan hutan; b) membantu pemerintah dalam pengelolaan hutan; c) menegakkan hukum adat tentang hutan; d) mengkoordinir pelaksanaan upacara adat yang berkaitan dengan hutan; dan e) menyelesaikan sengketa antara warga masyarakat dalam pemanfaatan hutan tugas (Pasal 31 Qanun Aceh Nomor 10 Tahun 2008).

\section{k. Peutua Seuneubok atau Nama Lain}

Peutua Seuneubok atau nama lain adalah orang yang memimpin dan mengatur keten tuan adat tentang pembukaan dan penggunaan lahan untuk perladangan/perkebunan (Pasal 1 angka 24 Qanun Aceh Nomor 10 Tahun 2008 tentang Lembaga Adat). Peutua Seuneubok atau nama lain dipilih oleh masyarakat kawasan Seuneubok atau nama lain. Adapun tata cara pemilihan dan persyaratan Peutua Seuneubok atau nama lain ditetapkan melalui musyawarah masyarakat kawasan Seuneubok atau nama lain sebagaimana diamanatkan Pasal 32 ayat (1) dan ayat (2) Qanun ini. Petua Seuneubok atau nama lain memiliki tugas (Pasal 33 Qanun Aceh Nomor 10 Tahun 2008) : a) mengatur dan membagi tanah lahan garapan dalam kawasan Seuneubok atau nama lain; b) membantu tugas pemerintah bidang perkebunan dan kehutanan; c) mengurus dan mengawasi pelaksanaan upacara adat dalam wilayah Seuneubok atau nama lain; d) menyelesaikan sengketa yang terjadi dalam wilayah Seuneubok atau nama lain; 
dan e) melaksanakan dan menjaga hukum adat dalam wilayah Seuneubok atau nama lain.

I. Haria Peukan atau Nama Lain

Haria Peukan atau nama lain adalah orang yang mengatur ketentuan adat tentang tata pasar, ketertiban, keamanan, dan kebersihan pasar, serta melaksanakan tugas-tugas perbantuan (Pasal 1 angka 25 Qanun Aceh Nomor 10 Tahun 2008 tentang Lembaga Adat). Haria Peukan atau nama lain dapat dibentuk untuk pasar-pasar tradisional (Pasal 34 ayat (1)). Pembentukan Haria Peukan atau nama lain tersebut dilakukan untuk pasar-pasar tradisional yang belum ada petugas Pemerintah (ayat 2). Adapun menyangkut pembentukan dan pengangkatan Haria Peukan atau nama lain dilakukan oleh Camat setelah berkonsultasi dengan tokoh-tokoh pedagang dan Keuchik atau nama lain setempat (ayat 4). Haria Peukan atau nama lain bertugas: a) membantu pemerintah dalam mengatur tata pasar, ketertiban, keamanan, dan melaksanakan tugas-tugas perbantuan; b) menegakkan adat dan hukum adat dalam pelaksanaan berbagai aktifitas peukan; c). menjaga kebersihan peukan atau nama lain; dan d). menyelesaikan sengketa yang terjadi di peukan atau nama lain (Pasal 36, Qanun Aceh Nomor 10 Tahun 2008).

m. Syahbanda atau Nama Lain

Syahbanda atau nama lain adalah orang yang memimpin dan mengatur ketentuan adat tentang tambatan kapal/ perahu, lalu lintas keluar dan masuk kapal/perahu di laut, danau dan sungai yang tidak dikelola oleh Pemerintah (Pasal 1 angka 26, Qanun Aceh Nomor 10 Tahun 2008 tentang Lembaga Adat). Ketentuan lembaga adat Syahbanda atau nama lain diatur dalam Pasal 38, Pasl 39 dan Pasal 40 Qanun Nomor 10 Tahun 2008. Lembaga adat Syahbanda atau nama lain dapat dibentuk untuk pelabuhan rakyat. Pembentukan Syahbanda atau nama lain dilakukan untuk pelabuhanpelabuhan rakyat yang belum ada petugas Pemerintah. Dalam hal Syahbanda atau nama lain telah dibentuk, maka petugas Pemerintah yang ditunjuk harus bekerjasama dengan Syahbanda atau nama lain. Pembentukan dan pengangkatan Syahbanda atau nama lain dilakukan oleh
Bupati/Walikota atas usul Panglima Laot atau nama lain dan tokoh-tokoh masyarakat setempat setiap 6 (enam) tahun sekali. Syahbanda atau nama lain memiliki tugas (Pasal 40, Qanun Aceh Nomor 10 Tahun 2008): a) mengelola pemanfaatan pelabuhan rakyat; b) menjaga ketertiban, keamanan di wilayah pelabuhan rakyat; c) menyelesaikan sengketa yang terjadi di wilayah pelabuhan rakyat; dan d) mengatur hak dan kewajiban yang berkaitan dengan pemanfaatan pelabuhan.

\section{Simpulan}

Berdasarkan hasil kajian tersebut di atas dapat disimpulkan bahwa sebagai berikut.

1. Keberadaan (eksistensi) masyarakat hukum adat dan kelembagaan adat yang ada di Aceh telah menunjukkan kiprahnya dalam tata kehidupan masyarakat di Aceh. Hal tersebut disebabkan oleh karena masyarakat hukum di Aceh telah memenuhi syarat-syarat masyarakat hukum adat (rechtgemeinschaap) sebagaimana sering dikemukakan oleh para ahli maupun dalam peraturan perundangundangan, khususnya pada bagian Penjelasan Pasal 67 Undang-Undang Nomor 41 Tahun 1999 tentang Kehutanan.

2. Keberadaan lembaga-lembaga adat di Aceh sebagaimana disebut dalam Pasal 98 ayat (3) Undang Undang Nomor 11 Tahun 2006 tentang Pemerintahan Aceh dan Pasal 2 ayat (2) (Peraturan Daerah) Provinsi Nomor 10 Tahun 2008 tentang Lembaga Adat, hakikatnya memiliki fungsi dan peran sebagai wahana partisipasi masyarakat dalam penyelenggaraan Pemerintahan Aceh dan pemerintahan Kabupaten/Kota di bidang keamanan, ketenteraman, kerukunan, dan ketertiban masyarakat. Selain itu, lembaga-lembaga adat tersebut juga memiliki sejumlah kewenangan sebagaimana yang diamanatkan Pasal 4 Qanun (Peraturan Daerah Provinsi)Aceh Nomor 10 Tahun 2008 tentang Lembaga Adat yaitu: a. menjaga keamanan, ketenteraman, kerukunan dan ketertiban masyarakat; b. membantu pemerintah dalam pelaksanaan pembangunan; c. mengembangkan dan mendorong partisipasi masyarakat; $d$. menjaga eksistensi nilai-nilai adat dan adat istiadat yang tidak bertentangan dengan syariat Islam; e. menerapkan ketentuan adat; f). menyelesaikan masalah sosial kemasyarakatan; $g$. mendamaikan sengketa yang timbul dalam masyarakat; h). menegakkan hukum adat. 


\section{Daftar Pustaka}

Anonim. 2012. Undang Undang Dasar Negara Republik Indonesia Tahun 1945

1999. Undang Undang Nomor 39 Tahun 1999 tentang Hak Asasi Manusia

2000. Undang Undang Nomor 41 Tahun 1999 tentang Kehutanan

2000. Undang Undang Nomor 44 Tahun 1999 tentang Penyelenggaraan Keistimewaan Aceh

2002. Undang Undang Nomor 32 Tahun 2004 tentang Pemerintah Daerah

2006. Undang-undang Nomor 11 Tahun 2006 tentang Pemerintahan Aceh

2000. Peraturan Daerah Nomor 2 Tahun 1990 tentang Pembinaan dan Pengembangan Adat Istiadat,

Kebiasaan-kebiasaan Masyarakat beserta Lembaga Adat di Provinsi Daerah Istimewa Aceh

2001. Peraturan Daerah Nomor 7 Tahun 2000 tentang Penyelenggaraan Kehidupan Adat

2005. Qanun Aceh Nomor 3 Tahun 2004 tentang Pembentukan, Susunan Organisasi dan Tata Kerja (SOTK) Majelis Adat Aceh (MAA). Qanun Aceh Nomor 3 Tahun 2009 tentang Tata Cara Pemilihan dan Pemberhentian Imum Mukim

2008. Qanun Aceh Nomor 9 Tahun 2008 tentang Pembinanaan Kehidupan Adat dan Adat Istiadat

2009. Qanun Aceh Nomor 10 Tahun 2008 tentang Lembaga Adat

1999. Keputusan Kongres Masyarakat Adat Nusantara No. 01/KMAN/1999

Azmi Siradjudin, 2004, April. Pengakuan Masyarakat Adat dalam Instrumen Hukum Nasional. Ihttp:// www.ymp.or.id

Ali Hasymy. 1989. "Kebudayaan Aceh Pada Hakikatnya Kebudayaan Islam”. Makalah. Disampaikan pada Seminar Sejarah dan Kebudayaan Aceh Selatan di Tapaktuan, 15 -16 Mai 1989.

Ali Muhammad Rusydi. 2003. Revitalisasi Syari'at Islam di Aceh: Problem, Solusi, dan Implementasi. Jakarta: Logos Wacana IImu

Bambang Sunggono. 1998. Metodo Penelitian Hukum. Jakarta: Raja Grafindo Persada

Badruzzaman. 2007. Membangun Keistimewaan Aceh dari Sisi Adat Budaya (MAA: Historis dan Sosiologisnya. Banda Aceh: Majelis Adat Aceh (MAA)

Hakim Nyak Pha dan Rusdi Sufi (ed). 2000. Adat dan Budaya Aceh. Balai Kajian Sejarah dan Nilai Tradisional. Banda Aceh: Fakultas Hukum Universitas Syiah Kuala

2001. "Pelaksanaan Syari'at Islam dan Hukum Adat di Aceh" Makalah. Disampaikan pada Lokakarya sehari Pelaksanaan Syari'at Islam di Daerah Istimewa Aceh, 29 Januari 2001.

sitas Syiah Kuala

Hardi. 1992. Daerah Istimewa Aceh: Latar Belakang Politik dan Masa Depannya. Jakarta: t.p.

Husni Bahri Tob. 2003. "Penyelenggaraan Pemerintahan Mukim Berdasarkan Qanun Nomor 4 Tahun 2003" Makalah. Disampaikan pada Pelatihan Imeum Mukim di Banda Aceh, 12 Agustus.

Kaoy Syah dan Lukman Hakiem. 2000. Aceh dalam Lintasan Sejarah. Jakarta: Pengurus Besar AlJami'iyatul Washliyah

Kurniawan. 2010. "Pengakuan dan Jaminan Perlindungan Konstitusional Terhadap Keberadaan Masyarakat Hukum Adat (Suatu Telaah terhadap Hak Masyarakat Hukum adat atas pengelolaan Tanah dan Sumber Daya Hutan di Nanggroe Aceh Darussalam)". Jurnal MONDIAL Fakultas Hukum Universitas Syiah Kuala. Darussalam - Banda Aceh. Vol.12. No.21. Edisi Januari - Juni 2010.

Masri Singarimbun.et.al. 1985. Aceh di Mata Kolonialis, Terjemahan dari The Achehnese Snouck Hugronje. Jakarta: Yayasan Soko Guru 
Mahdi Syahbandir. 1995. "Eksistensi dan Peranan Imuem Mukim dalam Pelaksanaan Pemerintahan Desa di Kabupaten Tingkat II Aceh Besar" Tesis. Bandung: Program Pascasarjana UNPAD

Moehammad Hoesin. 1970. Adat Atjeh. Banda Aceh: Dinas Pendidikan dan Kebudayaan Propinsi Daerah Istimewa Aceh

Peter Mahmud Marzuki. 2007. Penelitian Hukum. Jakarta: Kencana Prenada Media Group

Rony Hanitijo Soemitro. 1983. Metodologi Penelitian Hukum Normatif. Jakarta: Ghalia Indonesia

Rusdi Sufi. 2002. Struktur Pemerintahan Desa/Gampong di Aceh Dulu dan Sekarang. Banda Aceh: LAKA Provinsi Nanggroe Aceh Darussalam

Soerjono Soekanto. 1983. Hukum Adat Indonesia. Jakarta: Raja Grafindo Indonesia

Sandra Moniaga. 2002. "Hak-hak Masyarakat Adat dan Masalah Kelestarian Lingkungan Hidup” . Jurnal Wacana HAM. Jakarta. No. 10/Tahun II/12 Juni 2002

Sanusi M. Syarif. 2005. Gampong dan Mukim di Aceh Menuju Rekonstruksi Pasca Tsunami. Bogor: Pustaka Latin

T Djuned. 1977. Penyelesaian Sengketa Menurut Hukum Adat Aceh. Jakarta: Departemen Pendidikan dan Kebudayaan. Direktorat Jendral Kebudayaan. Balai Kajian Sejarah dan Nilai Tradisionil Banda Aceh

. 2003. "Kesiapan Sumberdaya Mukim dalam Mengemban Amanat UU No. 18 Tahun 2001 (Otonomi Khusus NAD)" Makalah . Disampaikan pada Diskusi Multipihak tentang Lembaga Mukim Dulu, Sekarang, dan Masa Akan Datang, diselenggarakan oleh LSM PUGAR, Banda Aceh, 3 Mei

2003. "Pemerintahan Mukim Masa Kini" Laporan Penelitian. Banda Aceh: Pusat Studi Hukum Adat Universitas Syiah Kuala, Darussalam, Banda Aceh

Taqwaddin. 2009. "Kewenangan Mukim dalam Pengelolaan Sumberdaya Alam" Jurnal IImu Hukum KANUN. Nomor 48. Edisi Desember 2009. Banda Aceh: Fakultas Hukum Universitas Syiah Kuala

2009. "Mukim sebagai Pengembang Hukum Adat Aceh" Makalah. Disampaikan pada acara Workshop Penguatan Institusi Lembaga Adat Melalui Pendokumentasian Hukum Adat, diselenggarakan oleh Jaringan Komunitas Masyarakat Adat (JKMA) Aceh dan GenAsist di Kecamatan Lhoong Kabupaten Aceh Besar, 11 Februari

. 2009. "Gampong sebagai Basis Perdamaian" Makalah . Disampaikan pada Lokakarya Perumusan Metoda Penerapan Nilai-nilai Kearifan Lokal untuk Mewujudkan Perdamaian Berkelanjutan di Aceh, diselenggarakan oleh Kabupaten Aceh Besar, 11 Februari 2009.

2008. "Penyelesaian Perkara Secara Adat Aceh" Paper. Banda Aceh: Fakultas Hukum Universitas Syiah Kuala.

2009. "Penguasaan Hutan Adat oleh Masyarakat Hukum Adat (Mukim) di Provinsi Aceh" Disertasi. Medan: Fakultas Hukum Universitas Sumatera Utara

Van't Veer Paul. 1977. Perang Belanda di Aceh (terjemahan oleh Aboebakar). Banda Aceh: Dinas Pendidikan dan Kebudayaan

Yance Arizona . 2008, Juni. Jaminan Hukum Masyarakat Adat. http://www.huma.or.id.

Zainuddin . 1961. Tarich Atheh dan Nusantara. Medan: Pustaka Iskandar Muda. 